This item was submitted to Loughborough's Research Repository by the author.

Items in Figshare are protected by copyright, with all rights reserved, unless otherwise indicated.

\title{
Disassembling actor-network theory
}

PLEASE CITE THE PUBLISHED VERSION

http://dx.doi.org/10.1177/0048393114525858

PUBLISHER

Sage (@ The Author 2014)

VERSION

AM (Accepted Manuscript)

PUBLISHER STATEMENT

This work is made available according to the conditions of the Creative Commons Attribution-NonCommercialNoDerivatives 4.0 International (CC BY-NC-ND 4.0) licence. Full details of this licence are available at: https://creativecommons.org/licenses/by-nc-nd/4.0/

\section{LICENCE}

CC BY-NC-ND 4.0

\section{REPOSITORY RECORD}

Elder-Vass, Dave. 2014. “Disassembling Actor-network Theory”. Loughborough University. https://hdl.handle.net/2134/17424. 


\title{
Disassembling actor-network theory ${ }^{1}$
}

\section{Dave Elder-Vass}

\author{
d.elder-vass@1boro.ac.uk
}

Note: This is a pre-publication version of a paper published in Philosophy of the Social Sciences. It may differ slightly from the published version. Please cite as: Elder-Vass, D. (2015) 'Disassembling Actor-Network Theory', Philosophy of the Social Sciences, 45:1, 100-121, and refer to the published version for the final wording and pagination.

\begin{abstract}
One of the strikingly iconoclastic features of actor-network theory is its juxtaposition of the claim to be a realist perspective with denials that supposedly natural phenomena existed before scientists "made them up". This paper explains and criticises such arguments in the work of Bruno Latour. By combining referent and reference in the concept of assemblages, Latour provides a superficially viable way to reconcile these apparently incompatible claims. This paper will argue, however, that this conflation of referent and reference leads Latour's ontology into difficulties that can only be resolved by abandoning it in favour of a more conventional - critical realism.
\end{abstract}

\footnotetext{
${ }^{1}$ Acknowledgements: this paper has benefited from my discussions with Bob Carter and Frederic Vandenberghe, with members of the Centre for Critical Realism (including Roy Bhaskar, Nick Hostettler, Lee Martin, and Nick Wilson), and with the Loughborough University Social Theory Reading Group (including Daniel Chernilo). I would also like to thank this journal's anonymous reviewers for a very productive set of comments.
} 


\section{Keywords}

assemblages; actor-network theory; critical realism; ontology

With postmodernism dead and poststructuralism struggling to find its way in the twenty-first century, the throne of iconoclasm sits vacant in the social sciences. But not, perhaps, for long: a new contender has emerged as heir apparent. Actornetwork theory (ANT, hereafter), if we may call it that while its advocates debate alternative nomenclatures ${ }^{2}$, is gathering momentum, certainly in Europe and on some of the more vocal and visible fringes of sociology. ${ }^{3}$ Having established themselves as the new orthodoxy in science and technology studies, the actor-network theorists (ants, hereafter) are now extending their influence by extending the reach of their trails. Bruno Latour, the leading figure in ANT, has critiqued mainstream sociology (Latour 2005) and the entire philosophical framework of the modern humanities and social sciences (Latour 1993) as well as taking an interest in law, democracy and the environment (Latour 2004, 2010). Meanwhile Michel Callon has led an ant assault on economic sociology (e.g. Callon 1998; Callon and Muniesa 2005; Callon, Millo, and Muniesa 2007). Here we see Latour practising what he preaches: building connections that enlist allies and extend ANT's range of influence beyond the ghetto of science studies. This is a strategy that has involved not only moving into new fields but also making links to other trends and traditions, notably the "new materialism" (Coole and Frost 2010), posthumanism and material semiotics (Haraway 1991; Hayles 1999), and complexity theory (Prigogine and Stengers 1984).

As an iconoclasm, ANT is rather distinctive. ${ }^{4}$ On the one, more familiar, hand, it gathers a sense of radicalism from its attacks on well-established traditions, including some that are close to many sociological hearts such as the work of Emile Durkheim and the tradition of social constructionism, as well as by making a string of intriguingly surprising claims about the nature of reality. On the other, and unlike the

\footnotetext{
${ }^{2}$ Latour, for example, has questioned the appropriateness of 'actor', 'network', 'theory' and even the hyphen (Latour 1999).

${ }^{3}$ Although Law has suggested that ANT "may be understood as a version of post-structuralism" (Law 2008: 623) the differences between the traditions are at least as substantial as the similarities.

${ }^{4}$ Latour even wishes to break the concept of iconoclasm itself, or at least to problematize it: (Latour 2010: $x)$.
} 
previous occupants of the throne, it claims to be a variety of realism (e.g. Latour 1999: 7; 2004: 231; Law 2004: 140) while dismissing more conventional realisms as 'naïve', and it offers a superficially straightforward approach to empirical work.

The primary focus of ANT is on empirical work, and in this space there are refreshing aspects of its approach: in particular the insistence on seeing each event as the outcome of a convergence of multiple interacting influences including those of material objects, all to be taken equally seriously by the investigator. Given this focus, it would perhaps be easy to dismiss some of the odder statements that accompany it as entertaining but not entirely serious iconoclasm. But if we do take them seriously, as I believe we should, these statements add up to an internally coherent and innovative ontology that conflicts with some of the most basic assumptions of most varieties of realism. This paper develops a critique - though an appreciative one - of the ontology of actor-network theory, from the perspective of one of those other realisms: critical realism. ${ }^{5}$ Although it is by no means the first discussion of the topic (see for example Mutch 2002; Krarup and Blok 2011; Vandenberghe 2002), it is striking that few professional philosophers have engaged with Latour's metaphysics (the outstanding exception being Graham Harman: Harman 2009; Latour, Harman, and Erdélyi 2011), and like Latour, I myself am a hybrid of social scientist and philosopher. Such hybridity may be desirable because it is by addressing problems in social science itself that the ontological issues become most apparent, but this casts us into a strange space where we are judged by multiple, sometimes conflicting, standards. As Latour puts it, "I'm like a dog following its prey, and then the prey arrive in the middle of a band of wolves which are called professional philosophers... My intention was not to fall in with the wolves and to have to answer all of these guys while trying to catch my prey" (Latour, Harman, and Erdélyi 2011: 41).

This paper does not engage with the history of the development of Latour's ideas, which is already well documented (Harman 2009; Latour 2013; Tresch 2013). Instead it begins by forefronting the oddness of some of ANT's intriguing claims about reality. It follows the trail that leads from these strangenesses to the concept (sometimes) known as assemblages, and the central role that this plays in the ontology of ANT. Then it contrasts assemblages with the ontology of entities, emergence, and

\footnotetext{
${ }^{5}$ This paper builds on (Elder-Vass 2008), delving much deeper into the concept of assemblages and its implications for ANT's ontology.
} 
causal powers offered by critical realism, and building on this offers a critique of ANT's ontology, a critique with two interwoven strands. First, a comparative strand, developed by contrasting it with a more conventional realist alternative; and second, a strand of immanent critique, arguing that in the end ANT's ontology fails to match up to the standards set by ANT's own rhetoric.

Despite this critical stance, I should stress from the outset that I see much of value in actor-network theory. Its attack on dualistic understandings of the social versus the 'natural' world, its insistence that nonhuman actors make a contribution to outcomes that are traditionally treated as social, its demand that when we do invoke the 'social' we must trace the connections that the term implies rather than taking them for granted; all of these are enormously healthy provocations to the sociological tradition (see Elder-Vass 2008). It is my contention, however, that these are all provocations that flow equally surely from a critical realist ontology, an ontology that not only sustains the more desirable elements of common-sense realism, but also avoids the incoherences into which the ANT version ultimately falls.

\section{Ferments and the phases of Venus}

Despite their claim to be realists of some sort, from time to time ants make claims that seem quite bizarre from the standpoint of conventional or common sense realism. Latour, for example, writes "Galileo may have constructed the phases of Venus, but once that construction was complete her phases appeared to have been 'always already present'" (Latour 1996: 23). And elsewhere he argues that ferments did not exist "before Pasteur made them up" (Latour 1999: 145). For the conventional realist the phases of Venus and the ferments really were 'always already present'. They were not 'constructed' or 'made up' by scientists, but discovered by them, although the terms and theories with which we describe and account for them were indeed constructed or made up, and may be re-constructed at some further point. The first strangeness of these claims, then, consists in them flouting the realist understandings we tend to take for granted - the natural attitude, as Schutz called it (Schutz and Luckmann 1974: 4). The second strangeness, though, is that such claims are allied with the claim to realism. According to Latour, for example, the facts 
constructed by scientists are nevertheless "the most ascertained, objective, and certified results ever obtained by collective human ingenuity" (Latour 2005: 89-90). And John Law tells us that "everything I argue assumes that there is a world out there and that knowledge and our other activities need to respond to its 'out-thereness"' (Law 2004: 7).

At first sight, Latour's account of ferments and the phases of Venus seems to be decisively idealist. On the one hand, he is saying, scientists' talk brings about the realities it describes, and on the other, those realities do exist in thoroughly physical forms. The implication would seem, at first sight, to be that our ideas conjure up physical realities in a way that even the most extreme constructionists would find hard to countenance. ${ }^{6}$ Yet, as we shall see, Latour's claim is not an idealist one at all. How can this be?

Taking something like Garfinkel's view that those occurrences which disrupt and problematize our normal assumptions are an important indicator of what is occurring behind the scenes, this paper will focus on these superficially bizarre claims as a way of getting to grips with the underlying ontology of actor-network theory. ${ }^{7}$

Getting to grips both in the sense of making sense of that ontology, and in the sense of offering a critique of it from a more conventional realist perspective. These claims, it will be argued, are not mere oddities, rhetorical devices that lend an air of radicalism to an otherwise pedestrian approach. On the contrary, they follow entirely logically from the underlying ontology of ANT, and it is by tracing back this logic that we can best make sense of the tradition and its implications.

\section{An ontology of assemblages}

Latour grapples most directly with the nature of the real in his book Pandora's Hope. This opens with a worried scientist asking him "Do you believe in reality?" to

\footnotetext{
${ }^{6}$ Rorty, for example, tells us: "Nobody thinks there is a chain of causes that makes mountains an effect of thoughts or words" (Rorty 1998: 72).

${ }^{7}$ Latour himself has professed a resistance to ontology, as a practice that seeks to unify the multiplicity of reality (Latour 2005: 120). Yet, as this paper will seek to show, ANT is strongly shaped by its underlying ontology. As Bhaskar has said, "denying the possibility of an ontology merely results in the generation of an implicit ontology" (Bhaskar 1975: 40) More recently, Latour seems to have accepted that he is indeed engaged in metaphysics (Latour, Harman, and Erdélyi 2011; Latour 2013).
} 
which his first answer is "But of course!" (Latour 1999: 1). Later in the book he discusses the case of Pasteur's work on fermentation. Recognising that his discussion might confuse us, he writes

'But', anyone with common sense would ask with an undertone of exasperation, 'did ferments exist before Pasteur made them up?' There is no avoiding the answer: 'No, they did not exist before he came along' (Latour 1999: 145).

Latour stresses that he is not making the neo-Kantian point that we can access nothing but our representations of ferments, which clearly did change when Pasteur came along: "This entails that we should be able to say that not only the microbes-forus-humans changed in the 1850s, but also the microbes-for-themselves. Their encounter with Pasteur changed them as well. Pasteur, so to speak, 'happened' to them" (Latour 1999: 146). Pasteur, he tells us, “encountered a vague, cloudy, grey substance sitting meekly in the corner of his flasks and turned it into the splendid, well-defined, articulate yeast twirling magnificently across the ballroom of the Academy" (Latour 1999: 145).

If we are to make sense of this, he tells us, we will need "to reforge the concepts that the modern settlement has given us with which to study such events" (Latour 1999: 145). The "modern settlement" to which he refers is the dualistic agreement, which he takes to be characteristic of all modern thinking, to divide the world into human and nonhuman (Latour 1993: 27-37), social and natural (Latour 1993: 30-31), politics and science (Latour 1993: 38), subject and object (Latour 1993: 56-7), speaking subject and referent (Latour 1993: 63-4), that to be interpreted and that to be explained. Reforging its concepts requires nothing less than a complete reinvention of ontology, and the central concept in Latour's new ontology is the concept of an assemblage, though many different terms are used in his work to refer to essentially this same concept - actor-networks, actants, actors, entelechies, monads and articulations, for example. Latour expresses no particular preference for any of these terms, and we may use any one of them to designate the concept he is working with. I have picked on 'assemblage' as it is burdened with few prior associations that might suggest connotations Latour himself would reject, and it seems most descriptive of what he means: an assemblage is a gathering. Conventionally, it refers to a temporary gathering of people, but for Latour we may think of it as a temporary gathering of influences. 
Although he often applies the concept to what we would normally think of as an 'object' or a 'thing', for Latour assemblages are not persistent things or indeed recurringly instantiated kinds of things or structures; central to this ontology is a denial of natural stabilities and repeatedly instantiated types. As Harman puts it, "For Latour an actant [and thus an assemblage] is always an event, and events are always completely specific: 'everything happens only once, and at one place'" (Harman 2009: 17) (the internal quote is from Latour 1993: 162). More recently there has been an attempt within ANT to enrol the concept of performativity to explain elements of stability or repeatability (see Law 2008: 634-5), and most recently of all, attempts to explain continuity, subsistence, and trajectory are central to Latour's interest in modes of existence (Latour, Harman, and Erdélyi 2011: 48; Latour 2013). By default, however, it is assumed that persistence will not occur:

It is always dangerous to imagine that at some point in history, inertia is enough to keep up the reality of phenomena that have been so difficult to produce. When a phenomenon 'definitely' exists this does not mean that it exists forever, or independently of all practice and discipline, but that it has been entrenched in a costly and massive institution which has to be monitored and protected with great care (Latour 1999: 155-6).

Rather, an assemblage is a contingent bundle of interactions between elements, a bundle of connections that's specific to a particular time and place: "an actor-network [ $=$ an assemblage] is what is made to act by a large star-shaped web of mediators flowing in and out of it. It is made to exist by its many ties: attachments are first, actors are second" (Latour 2005: 217). Or to turn to Law, drawing on Deleuze ${ }^{8}$ : "assemblage is a process of bundling, of assembling, or better of recursive selfassembling in which the elements put together are not fixed in shape, do not belong to a larger pre-given list but are constructed at least in part as they are entangled together" (Law 2004: 42).

This may seem reminiscent of the logic of systems theory, a connection that John Law has noted (Law 2008: 632). But in most systems theory we still have ordinary things, distinguishable material entities composed of smaller parts, which interact with each other and their environments. Assemblages are rather different from this. Perhaps what's most strikingly distinctive is that assemblages are not just composed of 'things' but also of our discourses about them. The assemblages that populate Latour's universe are not the kind of things that populate the universe of 
common-sense realism. They are not bundles of matter, organised into particular forms, about which we may sometimes know things. Instead, they are bundles of associations, and those associations include both what conventional realists think of as referents and also what we think of as reference.

This may not be quite as clear as it might be to those of us who approach ANT from a more conventional realist perspective because Latour's position implies that he cannot directly express, at least not while remaining within the terms of his ontology, the distinction between an object that exists independently of what we think about it, and an assemblage that includes both such objects and discursive elements. To do so would be to grant the objects independent existence of a sort, as parts that get coopted into assemblages, but for him the elements or associations that combine to form assemblages are assemblages too - there is no simple object (whether physical or otherwise) that is available to be combined into an assemblage. There's a kind of paradigm gap here, and Latour's explanations seem obtuse and confusing for those outside his paradigm because, I think, he wants to say that the assemblage includes both the referent and the reference but he is trying to say it without making it seem as if the referent and reference have separate existences which can then be combined, since that would be to accept the terms of the 'modern settlement' which he is rejecting.

\section{Beyond the paradigm gap}

Once we have seen across this particular paradigm gap, however, the strangenesses of actor-network theory no longer seem quite so strange - wrong, perhaps, as this paper will argue, but thoroughly consistent and plausible within the terms of Latour's ontology. Now we can see that "the splendid, well-defined, articulate yeast twirling magnificently across the ballroom of the Academy" is indeed a different assemblage than the "vague, cloudy, grey substance sitting meekly in the corner of his flasks" (Latour 1999: 15). Pasteur's 'microbes' or 'yeast' or 'ferments' are a different assemblage than the grey substance that came before or indeed than the grey substance that appears in more recent accounts of enzymatic reactions (Latour 1999: 151), because Pasteur's microbes are not just that same grey stuff, which Pasteur has now explained, but rather a bundle, an assemblage, of the grey stuff and

\footnotetext{
${ }^{8}$ The term assemblage comes from an English translation of Deleuze's agencement (Law 2009).
} 
his accounts of it. ${ }^{9}$ To put it in terms that we ordinary realists can understand, but which Latour would presumably reject, the grey stuff was the same for both but the rest of the assemblage was different. ${ }^{10}$ Because Latour recognises the existence only of the assemblage and not of the grey stuff as a thing in its own right, there is no thing, or kind of thing, that exists continuously across this transition.

As Latour says, "Before the notion of articulation, it was impossible to answer no to the question 'Did the ferments (or the microbes) exist before Pasteur' without falling into some sort of idealism" (Latour 1999: 147). Previously, such a statement would have entailed the belief that Pasteur's theorising could actually change the material grey substance in a way that defies our scientific understanding of the world. But now, it merely entails that the grey substance has been conjoined (or articulated) with a different set of terms and theories to form a new assemblage. The new yeast is not the same thing as the old grey substance. "Why not the same thing? Because it is not made out of the same articles, the same members, the same actors, the same implements, the same propositions" (Latour 1999: 150). The propositions, note, are part of the assemblage, they are not independent statements made about it. ${ }^{11}$ And hence when they change, the whole assemblage has changed: "Associations of entities have a history if at least one of the articles making them up changes" (Latour 1999: $152)$.

Latour, it would appear, is not just making a point about Pasteur's microbes, but making a general, indeed a universal, claim about ontology. He has appeared to waver on this point recently, saying of the claim that microbes did not exist before Pasteur: "if you take it as a metaphysical argument, it's completely ridiculous"

\footnotetext{
${ }^{9}$ A crucial point that is neglected in Harman's otherwise impeccable account of the problems with this statement (Harman 2009: 83, 123-6).

${ }^{10}$ Note that I do not mean by this to reaffirm an extreme dualism of reference and referent, but we can continue to recognise a distinction between the two without dividing them into features of fundamentally different and opposed segments of reality. Both reference (a mental but still physical property of a human being) and referent, for critical realists, are features of the same, unified, reality.

${ }^{11}$ There is some ambiguity here, because for Latour proposition may be yet another word for assemblage (Harman 2009: 82). I take the view that he uses the term to refer to meaningful statements, but also sees such statements as a variety of assemblage, formed by allying other assemblages, and wishes to suggest that other assemblages than meaningful statements by humans may be regarded as propositions too.
} 
(Latour, Harman, and Erdélyi 2011: 44). But he has made similar arguments on a number of other occasions, including his discussion of the phases of Venus, noted above, and the claim that we could not say that Ramses II died of tuberculosis because this disease had not yet been discovered in ancient Egypt (see Harman's comment in Latour, Harman, and Erdélyi 2011: 57).

He also makes a related point with regard to social phenomena: "For the sociologist of associations, any study of any group by any social scientist is part and parcel of what makes the group exist, last, decay or disappear" (Latour 2005: 33). This is not just Giddens's point about the ways in which sociological accounts may influence the behaviour of those who read or hear about them (Giddens 1984: 349350). Latour is careful here to say that any study of a social group is part of what makes it exist, meaning presumably that this is the case whether or not it influences the behaviour it purports to describe. This would seem to be because these sociological accounts become part of the assemblage concerned. Again, there is not a social group that exists separately from our accounts of it, but rather what we call a social group is an assemblage comprised of both referent and references. One further implication is that actor-network theorists take actors' accounts very seriously (Latour 2005: 55) (Callon 1986: 198-200), since these are again parts of the assemblage to which they refer.

People, too, are assemblages in this ontology (Law 2008: 632). Even human individuals are seen as variable bundles of influences, as in the case of the ironically named official, Mr. Petit: "Petit may speak for all French people, or for DATAR, or for one of DATAR's departments, or for a member of one of its departments, or in his own name, either as a transportation specialist or as a private individual. He may speak solely in the name of his own imagination" (Latour 1996: 44). Mr Petit, in this view, is not a physical human being of fairly stable structure and capacities, but rather an actor-network of variable influence depending upon the web of mediators that happen to be flowing through him on any particular occasion - including, in particular, how he is perceived; reference as well as referent.

For a final example, let us return to the phases of Venus that were first observed by Galileo. For ANT, this phenomenon springs into existence as a new assemblage when Galileo observes and reports it, because this is an assemblage that includes not only what we realists would consider an independent astronomical 
phenomenon, but also Galileo's account of them, Galileo himself, and the new telescopic methods required to observe them (reality, as Law puts it, "is not independent of the apparatuses that produce reports of reality" (Law 2004: 31)). The astronomical phenomenon then appears to have been 'always already there' but in fact what was already there, on Latour's ontology, was something rather different - a star, perhaps, that varied in brightness, along with the observations of it. For Latour, this latter assemblage is just as real as the new one - or at least it was at one time. There is a parallel here, for example, with the theory of spontaneous generation associated with Pouchet, which was replaced by Pasteur's theory of fermentation: "nor does the slow expulsion of Pouchet's spontaneous generation by Pasteur mean that it was never part of nature" (Latour 1999: 155). The clear implication is that "nature" is in part composed of the prevailing beliefs about it at any given time.

To make sense of disjunctions like these between what we now think was 'always already there', and what earlier generations perceived as being there, Latour introduces an innovative account of time. For critical realists, for example, the grey substances observed by Pouchet were the same kind of thing as the yeasts observed by Pasteur, but Pouchet was simply wrong about how they developed, and thus when we look back at Pouchet we can say that spontaneous generation never was part of nature, whatever theories of it existed at the time. For critical realists there is one historical past, but many theories about it, some of which may be wrong, including some past theories. But for Latour history itself is also composed of assemblages. A given year in the past, for example, "should be defined along two axes, not only one" - one axis identifying the year to which we are referring and the other the year from which we are referring to it, the year in which our sense of the original year is located. "In this second dimension there is also a portion of what happened in 1864 that is produced after 1864 and made retrospectively part of the ensemble that forms, from then on, the sum of what happened in the year 1864" (Latour 1999: 172). ${ }^{12}$ We find a similar argument in Law's discussion of the outbreak of foot and mouth disease in England in 2001. A later government report on the outbreak, he says "helps to enact one kind of foot and mouth $2001 \ldots$ it helps to make the reality of the past" (Law 2009).

To make sense of this, let us look back to a time (let us say the year 1600) before Galileo's first observation of the phases of Venus (in 1610). When we critical

\footnotetext{
${ }^{12} 1864$ is the year in which Pasteur developed his theory of airborne germs.
} 
realists do so, we believe, informed as we are by Galileo's work, that the phases of Venus existed at that time, though unobserved by humans. But Latour suggests a more complex perspective. From this view, in the assemblage the-year-1600-as-seen-fromthe-twenty-first-century, the assemblage we call the phases of Venus existed in 1600. But, for example, in the assemblage the-year-1600-as-seen-from-1601, the assemblage we call the phases of Venus did not exist in 1601. A realist might say that the phases of Venus themselves existed in 1600, although human knowledge of them did not. But for Latour it seem that this realist talk is already marked by the time in which the talking itself occurs and again he seems unwilling to allow that we can say things about a referent (here a time in the past) that have some validity independent of the act of reference itself.

Pasteur's ferments, then, as an assemblage of Paster's theories and the grey stuff to which they refer, did not exist before Paster "made them up". Yet once he had made them up, in the assemblages that followed the ferments were always already there, although in the assemblages that had preceded this moment they did not exist because what did exist were assemblages linking the grey stuff to other theories about it.

\section{Realism and causality}

Before evaluating this ontology of assemblages, it will be necessary to say a little more about the realist alternative that underlies this paper's critique: the ontology of critical realism. This is not the place to offer a substantial justification of such an ontology, which has been developed elsewhere (Bhaskar 1975; Elder-Vass 2010, particularly chapters 2-4). Instead, this section will offer a very brief summary of the most pertinent points; given its brevity it will necessarily ignore many important complexities.

For conventional realists of many varieties there are entities that exist and events that occur independently of what we may think or say about them (although some entities and events do depend on our concepts and/or our actions). Our accounts and theories of these entities and events are distinct from what they refer to, and may be right or wrong about them (Bhaskar 1975: 32). Furthermore, these entities and events may fall into kinds, which share common features, and at least some of these 
kinds of entities tend to be stably and persistently reproduced, independently of our efforts (Elder-Vass 2012: chapter 7).

Events, as critical realists understand them, are caused, but the realist account of cause is very different from the positivist understanding that is often taken for granted in the social sciences (see, in particular, Bhaskar 1975: Introduction). In the positivist account - such as Hempel's account of deductive-nomological explanation (Hempel 1968), based on Hume's understanding of cause as empirical regularity (Hume 1977 [1748]: 50) - a causal relation is one in which an event of type A always leads to a further event of type B; when this is the case, A is taken to have caused B, and there is nothing more to be said about how this might have happened. In the realist account of cause, by contrast, causal relations do not depend on exceptionless empirical regularities, nor do they take the form of one factor alone causing a subsequent event. Instead, actual events are caused by the interaction of multiple causal powers, and since on any given occasion a particular causal power may be frustrated by the operation of conflicting powers, there is no guarantee of empirical regularity, no guarantee for example, that if causal power $\mathrm{A}^{*}$ is operating that event $\mathrm{B}^{*}$ will result, even if $\mathrm{A} *$ tends to produce $\mathrm{B} *$ (Bhaskar 1975: 14).

Although there are certain similarities between this and ANT's account of events, there are also radical differences. The most striking similarity is that both are multiple determination accounts, in which any given event is the outcome of a contingent interaction of multiple forces (Bhaskar 1975: 109-111). But in the critical realist account, this element of contingency is combined with an element of consistency and repeatability that ANT denies, an element that in the realist model is provided by the concept of causal powers. A causal power is an emergent property of a thing or entity, a property that is possessed by all instances of a given kind of entity, by virtue of the characteristic composition and structure of members of this kind (Harré and Madden 1975: e.g. 5, 57, 92; Bhaskar 1975: e.g. 49-52). ${ }^{13}$ A laser pointer, to offer a simple example, possesses the power to project a spot of light onto a distant surface, because it consists of certain sorts of components combined in certain sorts of relations to each other, and this is true of all laser pointers that are so composed, though the realisation of this power in an actual event may depend on other

\footnotetext{
${ }^{13}$ Causal powers theories are also endorsed by other varieties of realists (e.g. Ellis 2002: 1, 3).
} 
contingently interacting factors - such as the battery being adequately charged, and the presence of a person pressing a button on the device.

Entities, then, have causal powers, which depend on the structure and composition of the entities concerned. The bridge between the structure/composition and the power is a mechanism - a process of interaction between the parts of the entity, which depends on this structure and composition (Bhaskar 1975: 14; ElderVass 2010: e.g. 23). In the case of the laser pointer, for example, the mechanism is (roughly, at a certain level of detail) that when the button is depressed it completes an electric circuit, with the result that electrical potential flows through the circuit that now connects the battery to the laser and stimulates the production of light by the laser. What ANT seems to deny, by contrast with this realist account, is the existence of types of things with consistent causal powers that contribute to the process of multiple determination (Latour 1999: 150).

Latour's view of Pasteur's ferments as an assemblage of Pasteur's theories and the grey stuff to which they refer, then, may be contrasted with the critical realist view that (i) ferments (which I shall call yeasts), both before and after Pasteur's scientific developments, were instances of a type of entity or object: a natural kind; (ii) that all instances of yeast, whenever they appear, share certain properties (e.g. the ability to ferment certain types of liquid) as a consequence of their characteristic composition and structure, irrespective of human understandings of those properties and structures; and (iii) that science produces beliefs about these properties and their causes which may be true or false, but which do not alter the existence or operation of those properties(Elder-Vass 2008; Bhaskar 1975: 17). For critical realists, the beliefs produced by science may well be (and arguably should be) influenced by our experience of the phenomena concerned, as well as other factors, and so there is something valuable about ANT's theorisation of scientific knowledge as a confluence of many diverse factors. Critical realists would even agree that specific occasions on which scientists interact with the phenomena under study are the result of such a confluence, and that specific occasions upon which, for example, yeasts are multiplied, are also influenced by scientists. But none of this entails that the existence of yeast as a natural kind or the possession by specific yeasts of the characteristic properties of that natural kind depends upon human intervention (Elder-Vass 2008: 458-9). There is at least some part of the world beyond us that is independent of us. 
This raises the question of the status of 'us' in this account. For critical realists, human beings are also entities with emergent properties and causal powers, and in this respect they are thoroughly analogous with material objects. ${ }^{14}$ There is no fundamental dualism of subject and object; we are all inhabitants of one continuous nature. In this respect, my argument is similar to Bloor's in response to Latour: "The word 'nature' refers to the all-encompassing, material system in which human animals and the entire pattern of their interactions, and all the products of their interactios, have their allotted place" (Bloor 1999: 87). ${ }^{15}$ But human beings are different inhabitants than entities of other types, because we are composed of certain characteristic types of parts, in certain characteristic dynamic relationships with each other, which give humans a distinctive set of powers and capacities. This is not to claim a special metaphysical status for humans: we could say the same of laser pointers or yeasts. But it does mean that we have capacities that make it possible for us to be subjects in the sense of beings who have the capacities, for example, to discuss the world, to explain events in it, and to refer to other things in the world, both in our communicative acts and within the structure of our beliefs. These capacities raise issues for humans that are not faced by any other non-human objects of which we are aware (except, perhaps at a lower level, by other animals with certain levels of linguistic capacity).

The most pertinent of these issues is the relationship of reference and referent. Acts of reference, and referential mental states, are for critical realists ordinary material events with emergent consequences, that are caused by multiple interacting factors like any other event. There is an echo here of ANT's recent attachment to material semiotics, which I take to mean that there is something similar between human acts of reference and the ways in which other kinds of entity react to their environments. But reference as it is experienced and enacted by human beings remains a power that other kinds of entity do not have. It exists materially in neural configurations that give rise to emergent mental properties, and in the material impact

\footnotetext{
${ }^{14}$ Equally, though it is not the focus of this paper, social structures are entities with emergent properties and causal powers: another claim that ANT would deny (Elder-Vass 2008: 462-8).

${ }^{15}$ However, critical realism's ontology ascribes causal power to both human and non-human entities symmetrically; whereas the Edinburgh School, whatever its formal commitments, tends to privilege human and social causes over natural causes, at least in its discussions of science (Latour 1999). 
our communications have on the world, but it exists separately from the objects to which it refers, even though those objects often have a causal influence on our acts of reference. Critical realism, therefore, provides us with ontologically-founded reasons for resisting the conflation of reference and referent in assemblages. ${ }^{16}$

\section{The trouble with assemblages}

Latour, despite his assertion of a belief in reality, questions the existence of an "outside world". But again, this does not mean what it might seem to: "When we say that there is no outside world, this does not mean that we deny its existence, but, on the contrary, that we refuse to grant it the ahistorical, isolated, inhuman, cold, objective existence that it was given only to combat the crowd" (Latour 1999: 15). This, again, is a comment on the dualism of what Latour calls the modern settlement. What he is denying is not the world, but a conception of a timeless material world that is decisively separated from the human, the warm, the subjective. This is a conception that was developed, he thinks, in opposition to the idea that the "unruly mob" could have authority over science and its creations; it represents an attempt to assert the independence of nature from society in a dualistic conception of the world. To deny such an independent nature is again consistent with his ontology of assemblages: for ANT, the world is out there but it is out there in the form of assemblages, in which the being of material things is inextricably bound up with specific (thus historical), human, subjective conceptions of them.

But what could it mean to say that the world exists only as assemblages? There is more than one way to interpret such a claim; let us consider three.

On the first interpretation, assemblages necessarily combine objects with our discourses about them and there are no objects distinct from such combinations there is no "isolated, inhuman, cold, objective existence". The implication of such a view would be that the world exists only through its relations with human actors. This seems both implausible and inconsistent with ANT's rhetoric. Implausible, because

\footnotetext{
${ }^{16}$ Bloor makes a step towards recognising this problem, when he accuses Latour of making "no systematic distinction between nature and beliefs about, or accounts of, nature" and links this to his rejection of the subject-object distinction, but does not go on to recognise the form in which Latour overcomes the distinction: the conflation of referent and reference in the concept of assemblages.
} 
our continuing discovery of new phenomena that appear to have existed before we found them suggests that there are indeed entities and events occurring in the world independently of any human involvement whatsoever. When scientists observe events in far off stars and galaxies, for example, that appear to have occurred thousands or millions of years before our observations of them, this radically undermines the claim that there is no "isolated, inhuman, ... objective existence" (stars, of course, are not cold!) Latour's reinvention of time gives him an internally coherent way to respond to such criticisms, but internal coherence is no guarantee of plausibility.

Furthermore, this way of understanding his ontology conflicts radically with ANT's rhetorical claims. Ants make enormous capital from the importance of treating the human and the nonhuman symmetrically, but to claim that the nonhuman exists only when and insofar as it is bound up with human reference to it would be a complete failure of such symmetry. Nonhumans, it would seem on this reading, are to be denied the very possibility of existing at all except insofar as they are represented by humans! This would be a return to the anthropocentrism that elsewhere Latour rejects, privileging the human rather than recognising the independent powers of the non-human, since in this ontology the world can only exist in and through assemblages that require a human component. The implications of his discussion of Pouchet's theory of spontaneous generation are similar: to say that this process was "part of nature" until Pasteur produced a contradictory theory is to confer being on a phenomenon on the basis of human perception of it, irrespective of the actual events being perceived. Once again, this reeks of anthropocentrism, and it does so because it assumes away the fallibilism that follows from more conventional forms of realism (Bhaskar 1975: 32). Humans can be wrong about the nonhuman, and unless we accept that Pouchet, for example, was wrong about spontaneous generation, and hence that it never actually occurred, whatever the views of the humans of the period, we are condemned to a view that privileges human belief over that to which it refers. ${ }^{17} \mathrm{By}$ contrast, more conventional realist positions are more symmetrical as a result of their acceptance that nonhuman phenomena exist independently of whether or not we perceive or refer to them (Harman 2009: 125-6).

\footnotetext{
${ }^{17}$ Hence in such cases Latour seems to commit what Bhaskar calls the epistemic fallacy (Bhaskar 1975: 36-9).
} 
On a second interpretation, Latour's argument could be read, not as saying that there can be no reality beyond assemblages with discursive content, but rather as saying (less radically) that we humans can only access reality in the form of assemblages with discursive content. On this kind of interpretation, there might be entities and events that are entirely independent of human beliefs, theories, and discourses, but there would be nothing at all that we can say about them - not least, because as soon as we did start to say anything about them then we would have started to bundle them up in assemblages with our discourse about them. This might seem superficially more plausible, but it is no more satisfactory than the first reading. Again, we can criticise it in terms of its implications for the study of events and in terms of its relation to ANT's larger project.

As far as the former is concerned, the argument may be trivially true but essentially irrelevant. Yes, once we start to theorise events in far distant galaxies, then we connect them up with discourses about those events - but this remains causally irrelevant to what has happened in those galaxies. The fact that once we talk about them we have connected them (for us) to discourse does not alter in the slightest what has happened in those galaxies or why it has happened. It is not assemblages that include human reference that act in those far distant galaxies, but entities that exist independently of us, and we are perfectly capable of understanding this. We can, in other words, say things about things that exist independently of us.

Nor is this interpretation any more satisfactory in relation to ANT's larger project. This argument, that humans can only access reality via human concepts of it, or via discursively derived categories of knowledge, is deeply implicated with the Kantian and neo-Kantian projects of which Latour himself is so dismissive. ${ }^{18}$ This argument is routinely deployed to deny that we can access the world beyond us at all, whereas Latour wants to say that we can and do access this world, but that the world which we access takes a form that combines the actual phenomena with epistemic associations. And it is routinely deployed to support the very dualisms that Latour is seeking to reject: in the Kantian version, the impossible-to-cross dualism between the human and the nonhuman worlds, and in the neo-Kantian version, the impossible-tocross dualism between the social and the natural worlds.

\footnotetext{
${ }^{18} \mathrm{Kant}$, for example, is accused of building a "palace of fallacies" (Latour 1999). And in Pandora's Hope Latour critiques the whole progression from Kant to the neo-Kantians (Latour 1999: 5-7). 
Let us consider, then a third way to read Latour's argument. On this interpretation, there are only assemblages in the world, and in all those assemblages in which we humans are implicated, discursive elements are present, but there may be other assemblages in which humans are not involved, which will not include discursive elements. However, social scientists are only interested in cases in which humans are implicated, whether as scientists or otherwise, and their world is populated by such assemblages, even if assemblages that do not include epistemic content do exist outside the spaces in which humans operate. Of course, this would require certain concessions on Latour's part: now, for example, we could no longer say that there is no "inhuman, cold, objective existence", since those assemblages that exist beyond human spaces do exist in just such a form. And it would become difficult to justify the insistence on treating all the objects of science as assemblages that depend on epistemic as well as physical associations - those distant galaxies, we now have to admit, do exist independently of us, even if scientific theories about them bundle up epistemic associations with empirical observations and the equipment that they depend upon, for example. We are now pulled back, it would seem, from the epistemic fallacy; knowledge claims and their referents are separated and can vary independently of each other. All this seems much more plausible, and for a good reason: in this account, assemblages are starting to collapse back into a more conventional realist view of the world. In saying so, I do not mean to suggest that such a modified ontology of assemblages is acceptable; only that this interpretation of ANT's ontology is no more consistent with the rhetoric of ANT's project than the others, since it can be sustained only at the price of giving up the very features that most decisively distinguish the ontology of assemblages from the ontology of common-sense realism.

Latour, then, is caught on the horns of a trilemma. On the first reading of his ontology, he would be committed to denying the existence of a world beyond that with which humans are engaged, and thus to an extreme form of anthropocentrism that conflicts with his insistence on treating the human and nonhuman symmetrically. On the second reading, he would be committed to denying human access to the world beyond reference or discourse, and thus to a form of Kantianism or neo-Kantianism that he has attacked mercilessly. On the third, he would accept that there might be assemblages that do not include human reference, but now he would have to give up 
some of the most original and distinctive claims to which he has pinned his colours. He would have to admit that those ferments, for example, existed before Pasteur came along.

No doubt Latour could escape into less ontologically ambitious readings of his work. We might say, for example, that he is not really making an ontological point at all with his notion of assemblages, and is just trying to express the ways in which the concepts that scientists work with are a complex product of empirical encounters and scientific controversies. Pasteur's concept of a ferment, then, was not one that scientists could engage with until Pasteur came along. But at this point the originality of Latour's grand project disappears in smoke. Is this really all there is to actornetwork theory?

Critical realism, I suggest, has a more persuasive way to approach these ontological issues: entities such as yeasts and planets exist independently of us, and we are capable of performing acts of reference in which we treat them as independent, while also recognising that the concepts we use to understand and explain them are products of human endeavour. Those concepts themselves have a material basis in the neural configurations of our brains - they do not belong to some dualistically separated realm of reality - but they exist separately from the things to which they refer - just as yeasts and planets exist separately from each other. This, in turn, is entirely compatible with believing that these separate things can influence each other causally, and that any given change is the product of multiple such influences. We can have the multiple complex interactions that ANT rightly insists upon without collapsing things into our descriptions of them, and thus avoid the anthropocentrism that such conflation threatens us with.

A great deal of the enormously productive empirical work that has been done under the banner of ANT is potentially compatible with this kind of realist approach to causation, and indeed much of it would benefit from such an approach. One benefit would be to remove the strange tension between the topic of science studies and ANT's approach to that topic. On the one hand we have sciences that often search for persistent and repeatable mechanisms possessed by identifiable types of things that exist independently of us, and on the other studies of science that claim to respect those sciences while rejecting this fundamental feature of the scientific enterprise. Another would be the ability to include social structures as causal forces. As Bloor 
has pointed out, social entities appear in Latour's accounts despite his theoretical antipathies towards them (Bloor 1999: 99-100). Realism, treating these as entities on just the same basis as other entities, allows them to be causal forces, while also agreeing with Latour that their causal efficacy also needs to be explained (Elder-Vass 2008)

\section{Conclusion}

Latour, I believe, is right to oppose the dualisms that have become deeply embedded in the social sciences (though not to believe that all social scientists other than actor-network theorists are prisoners to them). But opposition to dualism need not lead us as far as he wants to take us. We can accept that humans are part of the same world as those things we experience as being outside of us, with the implication that there is not an 'outside world' that is fundamentally distinct from the world that includes us as humans, but this need not entail that there is no difference at all between humans and other things in the world. For critical realists the distinctions between human and nonhuman, social and natural, reference and referent, epistemological and ontological are all useful and necessary distinctions, but they all refer to different aspects of one and the same ontologically unified world. Latour's ontology of assemblages is a fascinating and enormously ambitious approach to overcoming these dualisms, but in the end it is not a coherent or plausible one. We can do the same job much better, I suggest, with a more conventional style of realism.

\section{References}

Bhaskar, Roy. 1975. A realist theory of science. 1st ed. Leeds: Leeds Books.

Bloor, David. 1999. Anti-Latour. Studies in History and Philosophy of Science 30 (1):81-112.

Callon, Michel. 1986. Some elements of a sociology of translation: domestication of the scallops and the fishermen of St Brieuc Bay. In Power, action and belief, edited by J. Law. London: Routledge \& Kegan Paul. 1998. The laws of the markets, Sociological review monograph. Oxford: Blackwell/The Sociological Review.

Callon, Michel, Yuval Millo, and Fabian Muniesa, eds. 2007. Market devices, Sociological Review monographs. Oxford: Blackwell. 
Callon, Michel, and Fabian Muniesa. 2005. Economic Markets as Calculative Collective Devices. Organization Studies 26 (8):1229-50.

Coole, Diana, and Samantha Frost. 2010. Introducing the New Materialisms. In New Materialisms. Durham, NC: Duke UP.

Elder-Vass, Dave. 2008. Searching for realism, structure and agency in actor network theory. British Journal of Sociology 59 (3):455-73. 2010. The Causal Power of Social Structures. Cambridge: Cambridge UP. 2012. The Reality of Social Construction. Cambridge: Cambridge UP.

Ellis, Brian. 2002. The Philosophy of Nature. Chesham: Acumen.

Giddens, Anthony. 1984. The Constitution of Society. Cambridge: Polity.

Haraway, Donna. 1991. Simians, Cyborgs, and Women. New York: Routledge.

Harman, Graham. 2009. Prince of Networks: Bruno Latour and Metaphysics. Melbourne: re.press.

Harré, Rom, and Edward H. Madden. 1975. Causal powers: a theory of natural necessity. Oxford: Blackwell.

Hayles, N. Katherine. 1999. How we became posthuman. Chicago: University of Chicago Press.

Hempel, Carl G. 1968. Explanation in Science and in History. In The Philosophy of Science, edited by P. H. Nidditch. Oxford: Oxford UP.

Hume, David. 1977 [1748]. An enquiry concerning human understanding. Indianapolis: Hackett Pub. Co.

Krarup, Troels Magelund, and Anders Blok. 2011. Unfolding the social. Sociological Review 59 (1):42-63.

Latour, Bruno. 1993. The Pasteurization of France. Cambridge MA: Harvard UP. - 1993. We Have Never Been Modern. Cambridge, MA: Harvard UP. 1996. Aramis: or the love of technology. Cambridge, MA: Harvard UP. 1999. For David Bloor... and Beyond. Studies in History and Philosophy of Science 30 (1):113-129.

1999. On recalling ANT. In Actor network theory and after, edited by J. Law and J. Hassard. Oxford: Blackwell.

1999. Pandora's Hope. Cambridge, MA: Harvard UP.

2004. The Politics of Nature. Cambridge MA: Harvard UP.

2004. Why has critique run out of steam? Critical Inquiry (30):225-248.

2005. Reassembling the social. Oxford: Oxford University Press.

2010. The Making of Law. Cambridge: Polity.

2010. On the modern cult of the factish gods. Durham NC: Duke UP.

2013. Biography of an inquiry: On a book about modes of existence. Social Studies of Science 43 (2):287-301.

. 2013. An Inquiry into Modes of Existence. Cambridge MA: Harvard UP.

Latour, Bruno, Graham Harman, and Peter Erdélyi. 2011. The Prince and the Wolf:

Latour and Harman at the LSE. Winchester: Zero Books.

Law, John. 2004. After method: mess in social science research, International library of sociology. London: Routledge.

2008. On sociology and STS. Sociological Review 56 (4):623-649.

2009. Practising Nature and Culture. In Nature, Social Relations, and Human

Needs, edited by S. Moog and R. Stones. London: Palgrave.

Mutch, A. 2002. Actors and Networks or Agents and Structures: Towards a Realist View of Information Systems. Organization 9 (3):477-496.

Prigogine, Ilya, and Isabelle Stengers. 1984. Order out of chaos : man's new dialogue with nature. London: Heinemann.

Disassembling Actor-Network Theory 
Rorty, Richard. 1998. John Searle on Realism and Relativism. In Truth and Progress: Philosophical Papers, Volume 3. Cambridge: Cambridge UP.

Schutz, Alfred, and Thomas Luckmann. 1974. The Structures of the Life-World. London: Heinemann.

Tresch, John. 2013. Another turn after ANT: An interview with Bruno Latour. Social Studies of Science 43 (2):302-313.

Vandenberghe, Frédéric. 2002. Reconstructing humants. Theory, Culture \& Society $19(5 / 6): 51-67$.

\section{Author biography}

Dave Elder-Vass is a senior lecturer in sociology at Loughborough University. His writing on social ontology and social theory includes two recent books: The Causal Power of Social Structures (2010) and The Reality of Social Construction (2012). Currently, he is working on issues in the social ontology of economic phenomena, on the nature of cultural communities, and on giving as an alternative to market exchange. 